\title{
A Syntactic Analysis of Arabic Tense and Aspect
}

\author{
Abdullah S. Al-Dobaian* \\ Department of English and Literature, College of Arts, P.O. Box 2456, Riyadh 11451, King Saud University, Saudi Arabia
}

Corresponding Author: Abdullah S. Al-Dobaian, E-mail: maliknabi@ hotmail.com

\section{ARTICLE INFO}

Article history

Received: August 28, 2018

Accepted: October 21, 2018

Published: December 28, 2018

Volume: 9 Issue: 6

Advance access: November 2018

\section{Conflicts of interest: None}

Funding: This research is funded by Research Centre of the College of Arts at King Saud University

\section{Key words: \\ Arabic Tense, \\ Arabic Aspect, \\ Syntax, \\ Telicity, \\ Morphology, \\ Fåal, Yafial}

\begin{abstract}
I discuss the morphological analy sis of tense and aspect proposed by early Arab grammarians and illustrate some of its problems. In order to account for these problems, the Arab grammarians had to relegate the effects of tense and aspect to the morphological forms of faSal and $\mathrm{y}$ af $\mathrm{fal}$. I show that these forms marked different tense specifications other than the default past tense for faial and present or future tense for $\mathrm{y}$ af $\mathrm{fal}$. As for aspect it has only received a sporadic and inconsistent analy sis by early Arab grammarians. I agree with Fassi Fehri (1993) and Juhfah (2006) that a comprehensive theory of tense and aspect is essential for Arabic. I propose a syntactic analy sis of tense and aspect in Arabic based on MacDonald's (2008) analy sis with some modifications needed to account for the Arabic data. Unlike Fassi Fehri and Juhfah's analyses, this analy sis is based on the verb interaction with its arguments and modifiers in which the verb checks tense and aspect syntactically by moving to functional projections: aspect phrase and tense phrase. I argue that such syntactic analy sis consistently explains the interaction of tense and aspect in Arabic and their relevant specifications.
\end{abstract}

\section{INTRODUCTION}

Tense and aspect have got little attention in Arabic syntax. This study explores the problems of morphological view of early Arab linguists of tense and aspect. More specifically, the discussion of tense has been based on the traditional analys is of Arabic morphology of the verb dividing tense into two basic morphological forms: faial and yafial. FaSal is used for the past tense while yafial deals with the present and the future. As discussed below, even though the Arabic verb faSal and yafial are particularly specified with these marked tenses but can be identified with other tense types as well.

Aspect on the other hand has received a sporadic analys is relating it to the morphological verb. That is, the past tense faSal involves a completed event while yaf $9 a$ suggests a noncompleted event. However this clear-cut distinction may not be maintained as I explain below. This paper aims at providing a syntactic analysis of aspect and tense within the minimalist program. More specifically I provide a syntactic account explaining that tense and aspect are syntactically computed by means of the verb's interaction with its arguments within the VP. The verb checks its aspect and tense features in Asp and T heads respectively.

Published by Australian International Academic Centre PTY.LTD. Copyright (c) the author(s). This is an open access article under CC BY license (https://creativecommons.org/licenses/by/4.0/) http:// dx.doi.org/10.7575/aiac.alls.v.9n.6p.82
This paper is organized as follows. The second section explains the traditional analys is of tense and aspect in Arabic syntax. Then the modern studies are reviewed. In the fourth section, I provide a syntactic account of tense and aspect. Finally a conclusion summarizes the basic points of the paper. Below is a list of the used abbreviations: $3=$ third person, $2=$ second person, $1=$ first person, acc=accusative, nom=nominative, gen=genitive, juss=jussive, objective pro $=$ objective pronoun, $n e g=$ negation, $s=$ ingular, $\mathrm{p}=$ plural .

\section{THE TRADITIONAL ANALYSES OF ARABIC TENSE AND ASPECT}

In this section, Ireview the analys is of the early Arab scholars of tense and aspect in Arabic. Then I discuss one of the orientalist's studies. Finally I refer to the problems of the tense theory of early Arab scholars.

\section{The Traditional Theory of Arabic Tense}

Tense in classic Arabic theory is viewed as an integral part of the verb form involving an event with time (Almalaax 2009: 31). Based on this morphological view of tense, Sibawayhi assumes that the tense is tied to the verb form and every form 
has its own specified tense. Therefore the form faSal represents an event in the past as darsa. The past explains an action/event that has passed or in his terms 'ma mada'. yafial reports the present tense or in Sibawayhi's terms 'ma huwa kaa?in' as in yaqtul. The command reports an event that has not yet occurred and is expected to happen in the future, or what Sibawayhi's terms 'ma lam yaqa؟' as in ?udrus (Sibawayhi 1988,Vol. 1:12). To prove his point, Sibawayhi (1988, Vol. 1: 25) observes that the past is only compatible with the past adverb ?ams as in (1a) while radan is consistent with the future as in $(1 \mathrm{~b})$ :

(1) a. Pataytuka $2 \mathrm{ams} / *$ radan. came-1sm-objective pro yesterday/*tomorrow. I came to you yesterday $/ *$ tomorrow.

b. sa?atiika $*$ ?ams/radan. will come-1s-objective pro yesterday/*tomorrow I will come to you *yesterday/tomorrow.

Ibn Yafiish adopts the ternary tense distinction of the Arabic verb and assumes that the verb distinctively as sociates an event with time. More specifically, he discusses the role of speech time and the event time in the determination of tense (Ibn YaSiish, no date, Vol 7: 4). That is, the past tense is an event whose time had existed prior to the speech time while the future is an event that has not occurred yet and is reported to happen after the present moment or moment of speech. The present time, in Ibn YaSiish's view, represents a simultaneous correspondence between the event time and the speech time.

Alzajajii (1974: 86-87) focuses primarily on the past and the future tense. According to Alzajaajii, the past event passes by two times: the event time and the speech time. In other words, the event has already happened (i.e., the event time) and is being reported that such event had existed prior to the present moment of speech (i.e., the speech time). The future has not existed yet; thus no time has passed. As for the present, Alzajaajii (1974: 87) is not too clear about it. He views the present as a middle ground between the past and the future. On one hand, Alzajaajii believes that the present tense yafial is future. However he ambiguously concludes that the present tense may be used to express an event happening in the present moment or express an event that is about to happen in the future as in (2a). But once the particles seen or sawfa are used with the verb, the present tense is primarily used for the future as in (2b).

(2) a. Zaid yaquumu aliaan/ radan. Zaid

stands-3sm now/tomorrow Zaid stands now/tomorrow.

b. Zaid sa/sawafa yaquumu. Zaid will stand-3sm Zaid will stand.

Ibn Jenni links tense in Arabic to the morphological form of the verb and that the varying verb forms necess arily reflect a specific tense (Ibn Jenni, no date: 331). He states that: 'since the whole purpose of using verbs is to express tenses, different forms of the verb are used to signal the changes in tense (Ibn Jenni, no date: 331). Nonetheless he is quick to admit that the morphological verb form may end up having a different tense specifications from its default tense. In order to account for the inconsistency of the morphological verb form and tense, Ibn Jenni had to stipulate that it is perfectly legitimate to use a verb form beyond its predictable default tense provided that the speaker is aware of such usage. For instance, Ibn Jenni provides some examples of shifting tense in (3) (Ibn Jenni, no date: 331):

(3) a. ?in qumta qumtu.

If you stood up-2sm I stood up-1sm

If you stood up I stood up.

b. lam yaqum ?ams.

Not stood up-3sm yesterday

He did not stand up yesterday.

c. Paydaka Allahu.

may help-1sm-objective pro Allah

May Allah help you.

The sentence (3a) has the verbs qumta/qumtu that are used for the past tense; however, the past tense verb forms here signal the future tense because, as Ibn Jenni assumes, these verbs are used in the context of the conditional ?in that expresses the future. The present tense verb in (3b) indicates the past tense as evidenced by the use of the adverb modifier Pams due to the use of the negative particle lam. Finally, the past verb Paydaka in (3c) shifts its tense to mark the future as it is used for supplication as a wish to be accomplished in the future. The cases in (3), among other data that we will discuss later on, are empirical problems for the morphological tense theory of the verb proposed by early Arab scholars. Ibn Jenni draws our attention to some of these cases but does not explain why the morphological verb form has shifting case specifications. The explanation that Ibn Jenni proposes depends on the syntactic context which weakens the morphological approach of tense in Arabic.

From the discussion above, we can conclude that early Arab scholars represented by Sibawayhi, Ibn YaSiish, Alzajaajii, and Ibn Jenni viewed tense as a reflection of the Arabic morphological form. Moreover tense was determined by the speech time so that events (i.e., faSal forms) occurring before are past while those after it (i.e., yafSal forms) are considered to be in the future. The present tense yaf $9 a 1$ however was ambiguously analysed as being both present and future. However the ambiguity of the present tense is settled once the particles seen or sawfa are used and by then the verb primarily represents the future.

\section{Orientalist's View of Arabic Tense and Aspect}

In this section, I briefly review only one important study by Wright (1974).

Wright, like the early Arab scholars, focuses on the two Arabic of Arabic verb: faSal and yafial. He criticizes the concept of connecting tense in Arabic to the two forms since there are other types of tense like for example the future perfect and past perfect that are unrepresented by faSal and 
Yafa (Wright 1974: 51). The early Arab scholars as discussed before classified tense into the past, the present, and the future and devoted faSal for the past while yafial is for the present and the future. Almakhzuumii, agreeing with some of Wright's criticism of tense theory of the early Arab scholars, observes that faial and yafial may represent the simple tense distinctions of the past, present, and the future but may not however express the potentially different tense specifications allowed by the language like the perfect tense for instance (1986: 147).

Even though Wright criticizes the early Arab tense theory focus on the two verb forms, he however argues that the two forms express aspect and not tense (Wright 1974: 51). For example, Wright believes that faSal represents a finished or a perfective action whereas yaffal expresses an imperfective events. He lists all possible uses of the two verb forms. Unfortunately, he confuses tense and aspect and ends up making false statements. For example, Wright suggests that wishes or supplications as in (3c) above are completed actions. But they are not completed actions. Furthermore the past verbs in the context of conditionals as in (3a) are not perfective because the conditional particle expresses the future. Therefore not every past verb is perfective as Wright suggests. Moreover not every present verb in yaffal form is imperfective as implied by Wright. For example, Binnick reports Comrie's example of the Quranic verse: "Fa Allahu yahkumu baynahum yawma lqiyaamit" (But God will judge between them on the Day of Resurrection) (Binnick 1991: 437). The verb yahkumu is imperfective and involves a completed action as Binnick argues since it discusses finished actions in the Day of Resurrection contra Wright's claim (Binnick 1991: 437).

\section{Problems of the Traditional Analysis of Tense and Aspect in Arabic}

One of the serious problems of the traditional analys is is that the morphological verb forms are not exclusively used for the default tense. That is, faial is perfective, as observed by Wright (1974), and is used for the past while the imperfective yaffal marks the present and the future. However these forms may not consistently represent a specific tense. Instead, the two verb forms may be used in place of the other jeopardizing the theory of one-to-one mapping of tense and form of the early Arab grammarians. Below I refer to some data that pose problems to the traditional tense theory.

a. The contract terms like biStuka 'I sell you (this product)' involves a past tense form that refers to the present tense since the selling is established at the present moment of the speech. That is why Sibawayhi (1988 Vol 3: 24) observes that yaffal is used in place of faSal.

b. Although the traditional tense theory accounts for simple tense patterns like the past or the present or the future, it may not easily explain the complex tense structures. Let us examine the following sentences (examples are from Almalaax 2009: 326)

(4) a. kataba Zaidun ad-darasa Palaan.

wrote-3sm Zaid-nom the lesson-acc now

Zaid has written the lesson by now.

b. alyawma Ratmamtu Salaykum niSmatii (al-

Maa?idah, verse 3)

today completed-1sm upon you my blessing-acc

By today I have completed my blessing upon you.

Even though the past tense kataba and Patmamtu is used, it is not the simple past that is meant here because the adverbs Palaan and alyawma are inconsistent with the past. This suggests that the verbs in spite of their morphological form are not past. Almalaax (2009: 326) indicates that such verbs are present perfect. The event has started in the past and is completed at present hence the adverbs Palaan and alyawama are used.

c. Verbs of promise and conditional sentences refer to the future as they represent actions that are to be fulfilled in the future (Almalaax 2009: 156; Hasan no date, vol.1: 54). Let us examine the following sentences:

(5) a. ?iða kallamtanii saaSadtuka.

if called-2sm-objective pro helped-1sm-objective pro If you call me, I will help you.

b. Pinna PaStaynaaka alKawthar.

We granted-3pm-objective pro alkawthar-acc

We granted you a river in Paradise, alkawthar.

The verbs in the conditional sentence in (5a) and in the promise sentence (5b) are in the past tense morphologically. However these verbs are not in the past since they have not existed yet but are expected to take place in the future. That is why some Arab linguists considered such verbs to be future in terms of meaning (Hasan no date, vol.1: 54). These are problematic cases to the strict traditional tense theory.

d. Past tense verbs in Quranic verses of the Hereafter explain events that have not yet existed in the past nor they are existing in the present but they are going to happen in the future. For example, Pata Pamru Allahifa laa tastaAjiluuh 'The event (the Hour or the punishment of the disbelievers) ordained by Allah will come to pass, so seek not to hasten it) AlNahl verse 1 . In his interpretation of the verse, Ibn Saashuur (no date, vol: 96) suggests that even though the past tense is used, ?ata here describes an event that is destined to happen in the future, the Day of Judgment. In another verse, wa yawma yunffaxu fii lsuuri fafazi؟a man fii lsamawaati wa man fii lard $i$ 'And (remember) the Day on which the Trumpet will be blown and all who are in the heavens and all who are in the earth will be terrified' AINaml, verse 87. Ibn Saashuur (no date, vol 8: 46) observes that, like Pata in the previous verse, the past tense of the verb fafazi $a$ implies that the terrifying event is completed in the future since it is a feeling that quickly befalls people 
after the Trumpet is blown. yunffaxu is in the present tense form and it refers to the future. Reinforcing the future perfective meaning of the past tense verbs, Alhataarii (2006: 25) suggests that the change from yunffaxu which is in the present tense referring to the future to the past tense fafazi a $_{\text {expresses the quick }}$ perfective nature of the event terror.

e. The past verb can express the present tense to report the historical past or hikaayat ilhaal. Let us consider the following examples:

(6) a. haatha Zuhair alshaa@ir aljaahlii yuraajifu qasaydatahu

This is Zuhair the poet pre-Islamic reviews-3sm his poem-acc

This is Zuhair the pre-Islamic poet reviewing his poem. (This example is taken from Hasan no date, vol.4:340)

b. wa Allahu allathii ?arsala arriyaaḥa fatuthiiru saḥaaban. (Fater, verse 9)

And it is Allah who sends the winds, so they raise up the clouds.

The verb yuraaji 4 in example (6a) involves an event that had been completed long before the present moment. But the present tense event is used in order to report the event of reviewing the poems as if it exis ts now to give importance to the story (Hasan, no date, vol.4: 340). In the Qur'anic verse in (6b), the events of sending the winds and raising up the clouds are past events that happened prior to the present moment. That is why the verse starts with a past verb Parsala among other past verbs like fasuqnaahu 'drove the clouds' and fa?ahyayna 'revived the earth due to rain'. However fatuthiiru is in the present form to report a past event to bring about this great scene of raising up the clouds as as Sakkaaki indicates (1987: 247). The use of present tense in place of the past form proves that tense should not be linked to the morphological form. In order to explain the shift of tense from past to present, some scholars resort to eloquence motivations. For example, Alhataarii (2006: 5) cites Ibn al?atheer's observation that the change from the past to the present in fatuthiiru is for eloquence reasons, that is to draw a semantic scene of Allah's creativity in producing clouds. Some otherscholars like Almatlabii (1986: 72) think that the historical past is void of any tense. So the verb fatuthiiru for example is tenseless.

f. The present tense verb after the particle hatta is associated with two different tenses and two different case markings. Arab scholars observed that the tense of the verb as well as the case marking is determined by hatta. The morphological form itself cannot specify the tense of the verb. To illustrate, let us consider the following examples:

(7) sirna ḥatta nadxuluha/nadxulaha.

walked-3p until enter-3p-nom-objective pro now/enter$3 \mathrm{p}$-acc-objective pro future

We walked until we enterit. (The example is taken from AlFarahiidii 1985: 162)
Alfarahiidii (1985: 162) and Sibawayhi (Vol. 3, 1992: 20) assumed that the case assigner hatta is responsible for case marking of the following verb and its tense. Namely, if hatta is a beginning particle then the verb after it gets the nominative case as in nadxuluha and it is has a perfective meaning indicating that the event has already existed. However if hatta is used for a goal, hatta alFaa?iayah, the verb gets the accusative case as in nadxulaha and the event of entering is expected to take place in the future. The discussion of Alfarahiidii and Sibawayhi of tense and aspect of the present tense after hatta is revealing. On one hand it reinforces the strong interaction of tense and aspect in Arabic syntax that it is rarely discussed. On the other hand, the syntactic context plays an important role in determining tense.

The Arab scholars tried to provide explanations of the shifting tense for the verb that were not related to the morphological form of the verb. Instead the explanations were either related to the syntactic context of the verb as in (f) or were based on rhetorical motivations as in (C), (d), and (e) or the explanation is simply ignored as in (a) and (b).

\section{MODERN STUDIES OF TENSE AND ASPECT IN ARABIC}

In this section, I review the studies of FassiFehri (1993), and Juhfah (2006).

\section{Fassi Fehri (1993)}

Fehri (1993) discusses the two contrastive views on whether Arabic is a tense language as proposed by the early scholars like Sibawayhi in their analysis of faSal and yafial or if Arabic is an aspectual language as defended by Westem Semiticists such as a Wright (1974). Fehri believes that both tense and aspect should be part of a comprehensive theory. He argues that the traditional distinction of tense based on faSal and yaffal is problematic and it can only explain simple tense structures like the following examples Fehri (1993: 146):

(8) a. *kataba ar-rajulu rrisaalata radan.

wrote-3sm the man-nom the letter-acc tomorrow-acc The man wrote the letter tomorrow.

b. *ya-ktubu ar-rajulu ?amsi.

writes-3sm the man-nom yesterday

The man writes yesterday.

However, according to Fehri, the binary distinction between the past/non-past tense does not explain complex tense structures as the following examples illustrate (Fehri, 1993: 147-148):

(9) a. jalasa yasrabu al-qahwata. sat-3sm drink-3sm-nom the coffee-acc

He sat, drinking coffee.

b. kaana lwaladu yaliabu.

was the boy-nom play-3sm-nom

The boy was playing. 
c. sayakuunu lwaladu (qad)laSiba.

will be the boy-nom (already)

played-3sm

The boy will have (already) played.

In these examples, the sentences are complex consisting of two clauses: main and dependent each with its own tense specification. Such sentences are difficult to handle based on the past/non-past tense distinction of the early Arab scholars. At the same time these examples are also problematic for the western Semiticists' assumption of perfective/imperfective approach. Fehri argues that tense and aspect interact together in order to explain the examples in (9). For example, Fehri observes that the main clause verb jalasa in (9a) serves as an anchoring point for tense of the dependent clause verb $y a f r a b u$. Thus since the main verb is past, the other verb becomes past. Fehri also indicates that the aspect of the event is imperfective despite the fact that the main verb tense is past. As for (9b), kana is past while yaliabu is non-past and the tense therefore becomes past due to the main verb. The aspect of the event of the sentence is perfective even though that the dependent verb is non-past. Finally, the tense of the verb sayakuunu in $(9 \mathrm{c})$ anchors the tense of the subordinate verb and becomes future. The aspect of the event is perfective. Therefore, the complex tense structures such as imperfective past (9a), past perfect (9b), and future perfect (9c) cannot be accounted by the early scholars' theory of tense or by the aspect theory of the Semiticists.

\section{Juhfah (2006)}

Like Fehri (1993), Juhfah argues (2006: 49) that the early Arab theory of tense based on the morphological distinction between faSal and yafial does not account for the different tense possibilities in the language as well as separating tense from aspect (2006: 122). At the same time, he suggests that Semiticists' assumption that the Arabic two morphological forms are distinguishable in terms of aspect and not tense cannot be maintained (2006: 62). So he proposes a theory combining tense and aspect and mood (2006: 122).

Below I illustrate Juhfah's analysis of aspect in Arabic. Juhfah believes that aspect is a syntactic process that is compositionally computed by means of agreement relationship between the verb and its object (2006: 192). More specifically, the verb and the object agree with each other in a specifier-head relation and produces a perfective or telic reading when the verb has [+add] feature agreeing with the object [+quantity] feature. The feature [+add] is a verbal feature being associated with an event that can be counted. As for [+quantity], it is a nominal feature related to nouns that can be countable like chairs, cars but not mass nouns like water. In other words, in perfective actions we expect verbs and nouns to have the features [+add] and [+quantity] agreeing together. Otherwise if the verb is taking a mass noun for example, we expect the verb feature [-add] to agree with the object [-quantity] thus producing an imperfective reading. Then Juhfah, following the minimalist approach of Chomsky
(2015), after the checking of feature of the verb, the [-add] feature of the verb is deleted since it is uninterpretable while the [quantity] feature of the object is preserved since it is semantically relevant and thus interpretable (Juhfah, 2006: 192).

\section{SYNTACTIC ANALYSIS OF TENSE AND ASPECT IN ARABIC}

I provide a syntactic analys is explaining how aspect and tense apply. I follow MacDonald's analysis (2008) as it explains how the verb interacts with its internal arguments such as the object, the modifiers and the particles in order to generate the aspectual interpretations. Furthermore, the verb moves to Tense phrase (TP) to check its tense features. Therefore, aspect and tense features develop as a result of two basic syntactic relations: agreement and movement in two basic functional projections: AspP (Aspectual phrase) and TP. I start with aspectuality and then turn to tense discussion.

Aspectuality

In this section, I explain aspect and distinguish it from tense. Then I discuss the as pectuality of different types of verbs and also the aspectual properties of different noun types. Moreover, I illustrate some of the clues and evidence used in the literature to determine the (a)telicity of the event. Finally, I discuss the factors affecting aspect in Arabic verb phrase.

\section{Telicity vs atelicity}

Aspect is the internal organization of time of the event represented by the verb whether it has a definite endpoint, i.e., the event is telic, or the event is still continuing, atelic (Tenny 1987). Therefore, aspect is different from tense in which tense basically refers to time based on the utterance point.

Verbs in terms of their aspectual characteristics are classified into: accomplishment, achievement, activity or process, and stative (see Vendler 1967; Tenny 1987; Pustejovsky 1991; MacDonald 2008 among others). Let us consider the following examples:

(10) a. tasallaqa Sami al-jabala.

climbed-3sm Sami the mountain-acc

Sami climbed the mountain.

b. mata al-waladu.

died-3sm the boy-nom

The boy died.

c. nama Muhammadun baakiran.

sleep-3sm Muhammad-nom

early-acc

Muhammad sleeps early.

c. Sarah tuhibbu assafara.

Sarah like-3sf-nom travel-acc

Sarah likes to travel.

The verb tasallaqa in (10a) is an example of an accomplishment verb because the event denoted by the verb reaches its end when Sami gets to the summit of the mountain. Thus the action is telic. In other words, the event 
takes some time before it culminates and reaches a definite endpoint. The event of death mata in (10b) is usually instantaneous since it takes little duration to get to the final endpoint. Such verbs are called achievement. On the other hand, verbs in (10c and d) do not have endpoints; therefore, they are atelic. The verb nama is a process (in Pustejovsky's terms 1991) or an activity verb (Tenny 1987) that has a beginning but no end. Finally, tuhibbu deals with a state that does not have a terminating point.

The aspectuality of the event of the verb is determined by the internal components of the VP such as the object and modifiers that I will consider later; for now, I will consider the object. The object affects the event's telicity and it can either produce one indivisible event or divide the event into further smaller events (Juhfah, 2006; Tenny 1987; MacDonald 2008). Let us consider first the effect of object on the (a) telicity of the event.

(11) a. Saraba Muhammadun kaa?san min al-ḥaleebi fii saaiateen.

drank-3sm Muhammad-nom one glass-acc of milk-gen in two hours

Muhammad drank one glass in two hours/for two hours.

b. Sariba Muhammadun al-ḥaleeba *(fii saaSateen)

drank-3sm Muhammad-nom milk-acc in two hours Muhammad drank milk in two hours.

The drinking of one glass of milk in (11a) is a telic event that can be measured out by the consumption of one glass over the specified time in the adverbial phrase. As the glass is finished the event is completed as the two hours elapsed. The use of the adverbial modifier fii saafateen serves as the time duration by which the event comes to an end. However, when the object is a mass or non-count noun as in (11b), the event becomes atelic since the event of drinking milk does not have a logical termination point as evidenced by the ungrammaticality of the adverbial modifier. The modifier fii saaYateen forces the event to be delimited after this period of time which is incompatible with atelic nature of the mass $\mathrm{s}^{\mathrm{c} .}$ noun alhaleeba. So the two nouns in (11) have different aspectual properties: one is countable, i.e., kaa?san min alhaleebi, and involves a telic event. The other noun is non- $\mathrm{d}$. countable and atelic as evidenced by the ungrammaticality of the modifier. Besides influencing the telicity of the event, the object may also determine if the event of the verb involves one or multiple events. Consider the following examples:

(12) a. naama al-waladu lisaaSateen.

slept-3sm the boy-nom for two hours

The boy slept for two hours.

b tasallaqa Sami al-jabala lisaaiateen.

climbed-3sm Sami the mountain-acc for two hours Sami climbed the mountain for two hours.

As we observed in (10c and a), nama is atelic since the event has no endpoint; whereas tasallaqa is telic. The durative adverbial is nonetheless used with both verbs with the interpretation that there is only one single event of sleeping that continues without any indication of termination and therefore no repetition. However, in an event that has a termination point as in climbing a mountain in (12b), the durative adverbial suggests a series of events within the two hour period. So we expect climbing events to happen over and over within the time frame of durative adverbial. Tenny (1987: 22) and MacDonald (2008: 33-35) report the same observation in English where durative adverbials produce single event interpretation when used with atelic verbs and multiple event reading with telic verbs.

Having discussed as pectual properties of verbs and nouns, we are in a position discuss the factors affecting aspect in Arabic verb phrase. What controls aspect? Is it morphology or syntax? We have already observed that morphology cannot determine aspect in Arabic since the Orientalist's (as discussed in section 2.2) binary distinction of yafial as imperfective or atelic and faSal as telic or perfective has empirical problems and we have discussed some of these problems in section (1.3) above. For example, fa fal can express the imperfective while yaffal may be used for the perfective aspect. However, we cannot dismiss that there are some morphological markers of aspect. Among these morphological markers are commencement verbs or muqaarabah verbs such as kaada and Pawfaka, beginning verbs as SaraYa and Panfa?a, hope verbs as Yasa, and other nawasix verbs like maazaala and maanfakka. All these verbs make the event imperfective. Let us consider the following examples:

(13) a. Saraia al-waladu yaktubu ad-darasa.

Started-3sm the boy-nom write-3sm-nom the lesson-acc

The boy started to write the lesson.

b. Sasa al-waladu yaktubu ad-darasa.

It is hoped the boy-nom write-3sm-nom the lessonacc

It is hoped the boy write the lesson.

c. mazaala al-waladu yaktubu ad-darasa.

still the boy-nom write-3sm-nom the lesson-acc The boy still writes the lesson.

d. kaada Sami yatasallaq al-jabala (laakinnah xaafa or tas allaq qaliilan).

almost Sami climbed-3sm the mountain-acc (but he was afraid or climbed little

Sami almost climbed the mountain.

The events of verbs in (13) are incomplete because the final result is not reached due to the use of these morphological elements. The events prescribed by these verbs in (13) consist of a beginning and a result and these verbs emphasize that the events have already begun as in $(13 \mathrm{a}, \mathrm{c})$ or is hoped to begin in the future as in (13b) or is about to begin as in (13d) but the result is not achieved. It is interesting that kaada behaves similarly to almost in English. Like almost, kaada may ambiguously have two possible interpretations when used with an accomplishment verb like yatasallaq: kaada can modify the beginning of the event so that the event almost begins and that the event has not begun 
because Sami was afraid. This is what MacDonald calls the counterfactual interpretation (MacDonald 2008: 64). We get the second reading however when kaada refers to the end of the event in which the event begins and almost ends and the meaning is that Sami climbed some part of the mountain but not entirely. This is called an incompletive interpretation (MacDonald 2008: 64). Now let us examine how atelic verbs are used with kaada:

(14) a. kaada al-walad-u yadfaSu as-sayyaart-a (laakinnah rayyara ra?ayahu).

almost the boy-nom push-3sm-nom the car-acc but he changed his mind

The boy almost pushed the car.

b. *kaada al-walad-u yuhibbu as-safara.

Almost the boy-nom like-3sm-nom travel-acc

*The boy almost loved to travel.

An activity verb in (14a) has a beginning but no end (MacDonald 2008: 67); as a result, kaada only modifies the beginning of the event and the only interpretation we get is that the event of pushing the car has not begun. Thus the event is atelic with no end result. As MacDonald (2008: 67) suggests, a stative verb yuhibbu has no beginning and no end; therefore, kaada may not be used since it cannot modify the beginning nor the end of the event making the (14b) ungrammatical.

Finally, I discuss the how the internal arguments within the VP structure play a role in the aspectuality of the verb.

So far we have analysed the role of object in determining the aspectual properties of the verb and this is consistent with what Juhfah argues (2006). However Juhfah (2006) does not discuss the goal and source modifiers' influence on aspectuality of the Verb. To illustrate, the goal modifier describing the goal of the verb and the source modifier describing the source of the verb both delimit the event and mark a culminating point for the event. Let us consider the following example:

(15) a. al-walad-u yadfa@u as-sayyaart-a naḥwa mahatat-i

il-raaz-i.

the boy-nom push-3sm-nom the car-acc to the station gen gas-gen

The boy pushes the car to the gas station.

b. al-walad-u yadfaiu as-sayyaart-a xaarija mahatat-i ilraaz-i.

the boy-nom push-3sm-nom the car-acc out of the station-gen gas-gen

The boy pushes the car to the gas station.

Tenny (1987: 180) considers the source and goal as oblique arguments of the verb both of which mark an end to the event of the verb. Without the use of such modifiers, the verb yadfa@u is atelic or non-delimited as we can observe in (14a) above.

\section{AspPhrase: a functional predicate for aspect}

As we observed in the previous section, the aspect is calculated syntactically by means of the verb interaction with its internal arguments (see Fassi Fehri, 1993 and Juhfah, 2006). For example, the verb becomes telic or atelic depending on the type of the object whether it is countable or not as in examples (11) above. Other constituents inside the VP, like oblique arguments as discussed in examples in (15), also affect the telicity of the verb. So it makes perfect sense to analyse aspect as a syntactic process performed between the verb and its internal arguments. One way to do this is to assume that aspect is developed by means of syntactic functional projection that we consider to be an Aspectual functional projection or phrase, AspP. In fact, this is what MacDonald (2008) argues for and I use his analysis with some modifications required by the Arabic data as it can account for its aspect better than other analyses as Juhfah's (2006).

The AspP is situated between vP and $\mathrm{VP}^{1}$. MacDonald assumes that aspect has its own functional projection and he cites researchers like Travis (1999; 2000), Borer (1994; 1998; 2005), Ritter \& Rosen (1998, 2000). The interesting innovation of MacDonald's proposal is that aspect is syntactically calculated in AspP by means of agreement, a syntactic principle, between the object in the lower VP shell and Asp head. MacDonald calls this process object-to-event mapping (OTE) (MacDonald 2008: 4). Furthermore, there is a direct interaction between OTE and event structure features. Now we examine how this analysis works. First, let us discuss the basic event features of the main four as pectual classes of verbs (MacDonald 2008: 28):

(16)
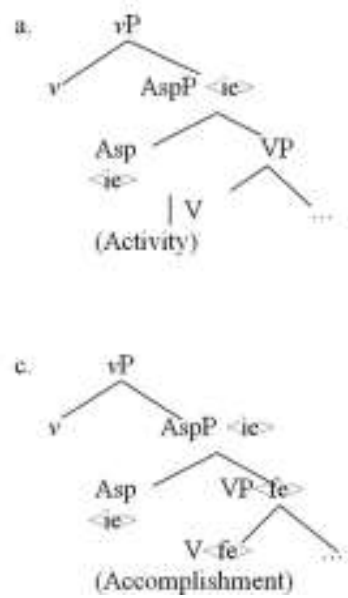

d.

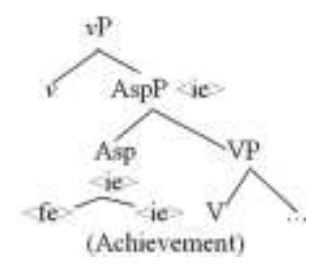

The event of an activity verb like walk has only a beginning symbolized as initial subevent (ie) and no end. This feature is marked on the Asp head and then it projects to the higher node, AspP. So the event of activity (i.e., AspP) has a beginning feature. As for the stative as love, its event has no beginning or end features. Therefore, it has no aspectual projection. An accomplishment verb as build a mosque is specified with a beginning feature on the Asp head and an end feature that is marked on the verb head. The features project to the higher nodes respectively: AspP and VP. MacDonald relates the two features by a c-command 
relation ${ }^{2}$. That is, the <ie > under the Asp head c-commands the $\langle\mathrm{fe}\rangle$ feature dominated by VP as (16c) illustrates hence explaining the elapse of time between the beginning and the end of the event. On the other hand, in an achievement verb like die there is noc-command between $\langle\mathrm{fe}\rangle$ and $\langle\mathrm{ie}\rangle$ since they are dominated by the same Asp head as shown in (16d). MacDonald (2008: 28) relates the lack of c-command to the lack of time elapsing between the beginning and the result of the event. Telic events like accomplishment and achievement always involve beginning and features whereas atelic events of activity verbs are either associated with beginning feature or with none as stative verbs (MacDonald 2008: 28). The event features agree with event structure modifiers like almost. To illustrate, consider the use of the modifier kaada 'almost' with an accomplishment verb in (13d) above repeated in (17) for convenience.

(17) kaada Sami yatasallaq al-jabala.

almost Sami climbed-3sm the mountain-acc

Sami almost climbed the mountain kaada ambiguously has two possible interpretations: kaada can modify the beginning feature on the AspPso that the interpretation is that the event almost begins but the event has not begun because Sami was afraid. This is the counterfactual interpretation. We get the second reading however when kaada modifies the end feature that is projected to the VP shell generating an incompletive interpretation in which Sami climbed some part of the mountain but not entirely. When kaada is used with an achievement verb, the modifier has a different behaviour.

(18) kaada Muhammadun yasqut. almost

Muhammad-nom fall-3sm

Muhammad almost fell.

The sentence in (18) has an achievement verb yasqut since it can be modified by what Pustejovsky (1991: 50) calls point adverbs that prove the event has a definite simultaneous endpoint. The sentence can be modified by at noon or any specific point time adverbials. Now if kaada is used we have one possible reading which is the counterfactual interpretation because kaada only modifies the beginning of the event. So the meaning becomes falling almost happened but it did not occur. As the tree diagram (16d) shows, the beginning feature <ie> projects to Asp leaving the end of event feature $\langle\mathrm{fe}\rangle$ behind. As a result, the beginning feature becomes visible syntactically while the end feature is not and thus kaada can modify only the beginning feature ${ }^{3}$. Here an achievement verb differs from an accomplishment verb since the two features are projected in two syntactically visible nodes as illustrated in (16c) thus generating ambiguity with kaada. Pustejovsky (1991: 51) reports the same observations in similar sentences in English with the use of almost. Like achievement, an activity verb yadfaSu assayyaart is unambiguous with kaada as in (14a) since the modifier accesses the beginning feature producing the counterfactual interpretation. Finally, kaada cannot be used with the stative yuhibbu in (14b) because there are no beginning and end features to modify.
After discussing the event structure features, let us now examine OTE and how it interacts with event features. Consider the following example.

(19) a. Pakala Sami tufaahatan.

ate-3sm Sami an apple-acc

Sami ate an apple.

b. ?akala Sami ruzzan.

ate-3sm Sami rice-acc

Sami ate rice.

The object tufaahatan is countable and thus it provides a scale in which the object measures out the event of apple eating until it is completely consumed and the event is finished as evidenced by the use of the time span adverbs as fii daqiiqatiin "in two seconds". Thus the event is telic and the object here is countable and specified with $[+q]$ which marks a specified quantity. MacDonald (2008) argues that such object with $[+q]$ agrees with the Asp head and values it as telic. However, the object ruzzan in (19b) is uncountable since it does not have a specified category of material. As a result, this object is associated with [-q] and it agrees with Asp head and values it as atelic making the event of rice eating atelic as evidenced by the impossibility of using fii daqiiqatiin. So OTE or the object therefore plays a role in mapping the event of the verb with right aspectual interpretation. MacDonald (2008: 80) argues that OTE interacts with event structure features. For instance, as the object tufaahatan is [+q] agreeing with Asp making it telic, the end feature $\langle\mathrm{fe}\rangle$ marked on VP contributes to the interpretation of the event. But the end feature of the subevent in (19b) does not contribute to the event of Asp since Asp is atelic because ruzzan is [-q] and it agrees with it.

I agree with MacDonald that the internal object of the verb affects the event aspectuality but there are other VP constituents that also play a role, namely the oblique arguments. MacDonald argues that only the internal object determines the telicity of the event of the verb while the goal prepositional phrase (goal PP) does not as in the following example (MacDonald 2008: 177).

(20) John complained to his boss.

MacDonald observes that the predicate complained is atelic and there is no internal object with $[+q]$ that can make the event telic. He argues that even though the goal NP is $[+q]$, i.e., boss is countable and hence is $[+q]$, this goal does not influence the telicity of the event of the verb which is atelic. In order to ensure that boss does not affect the event aspectuality, MacDonald argues that the prepositional phrase to his boss is blocked from agreeing with Asp. However, this conclusion cannot be maintained. For one thing, what Macdonald assumes in (20) to be goal PP is not the goal PP delimiting the event. To illustrate, consider the following example.

(21) a. al-walad-u yadfaiu as-sayyaart-a.

the boy-nom push-3sm-nom the car-acc

The boy pushes the car.

b. al-walad-u yadfa@u as-sayyaart-a naḥwa maḥatat-i il-raaz-i. 
the boy-nom push-3sm-nom the car-acc to the station-gen gas-gen

The boy pushes the car to the gas station.

The verb yadfa@u in (21a) is an activity verb that is atelic since it has no implied end point to its event as evidenced by the impossibility of using the time span adverb fii xamsi daqaaiiq "in five seconds" in (21a). Once a goal modifier is used as in (21b) the verb yadfa@u changes from an activity to an accomplishment and becomes telic as evidenced by the use of fii xamsi daqaaiiq. The same can be equally said about another type of oblique argument which is the source PP that I discussed in (14b) above. In accordance to MacDonald's blocking analysis, the goal modifier should be blocked from affecting the telicity of the event. But because the event of the verb in (21b) becomes telic due to the goal modifier the blocking analysis is problematic. In fact, Pustejovsky (1991: 49) provides similar examples to (21) of an English activity verb that is atelic like Mary walked and such sentence becomes an accomplishment and hence telic by the use of goal modifier as in Mary walked to the store. The noun mahatati ilraazi in the goal modifier nahwa mahatati ilraazi is specified with $[+q]$ and it agrees with the Asp making it telic ${ }^{4}$.

Other VP constituents affecting the verb event are internal arguments of unaccusative verbs that MacDonald does not discuss (2008: 83). In section 2.3, I addressed some problematic data for aspect in Arabic. Some of these data are the following:

(22) a. Pata Pamru Allahi fa laa tasta@jiluuh.

(AINaḥl, verse 1)

The punishment (of the disbelievers) ordained by Allah will come to pass, so seek not to hasten it.

b. wa yawma yunffaxu fii lsuuri fafazi९a man fii ls amawaati wa man fii lardi. (AlNaml, verse 87)

And (remember) the Day on which the Trumpet will be blown and all who are in the heavens and all who are in the earth will be terrified.

As explained in section 2.3, these Quranic verses discuss events in the future and the past tense is used to express completed actions. If we examine these past verbs like ?ata 'came' and fafazila 'was afraid', we observe that they are achievement verbs since they both can be modified by point adverbs like at noon suggesting that these verbs are delimited by this time. Achievements as we discussed previously are events whose beginning and end happen simultaneously or at least there is a short time elapse between the beginning and the end unlike accomplishments. These types of verbs involve movement and change of state in which the event change from one state to another, e.g.fafazi a from not afraid to being afraid. These verbs are called unaccastives and they have an internal argument originating in the object position and then it moves to the subject position for case (Haegeman 1994: 333). The internal argument of Pata and fafaziSa is specified as $[+q]$ and agrees with the Asp head and values it as telic.
To summarize this section, we can conclude that MacDonald's aspectual analysis would handle the Arabic data better if we assume that a telic interpretation is not only due to direct objects but also oblique arguments of the verb as well as internal arguments of unaccusatives with [+q] agreeing with an Asp head. Otherwise we would expect atelic reading in which the Asp head is valued as [+q]. Similar to MacDonald's, Juhafah's analysis (2006: 192) proposes that aspect is a syntactic process that is compositionally computed by means of agreement relationship between the verb and its object. More specifically, the verb and the object agree with each other in a specifier-head relation and produce a perfective or atelic reading depending on whether the verb has [+/- add] feature agreeing with the object [+/- quantity] feature. Then after checking the features, the [add] feature of the verb is deleted by LF since it is uninterpretable while the [quantity] feature of the object is preserved since it is semantically relevant and thus interpretable. There are at least two problems with Juhfah's analysis. The first problem is that it considers the direct object as the only source determining aspectual interpretation of the verb event as MacDonald's analysis does. Secondly it is a costly process to assume that a verb, in its agreement with the object, is characterized with [+add] feature, for telic event, and [-add], for atelic event. Then we delete these features of the verb at Logical Form (LF) because they are uninterpretable given the fact that they do not add anything to meaning.

\section{Tense checking and TP}

As we have observed in section 2.1, the early Arab scholars linked tense to the Arabic morphological forms: faSal and yaffal. However, these forms can be as sociated with multiple tense specification as explained in section 2.3. Consider the following examples:

(23) a. biituka al-qalam-a?alaan.

I sell-2sm-objective pro the pen-acc now I sell you the pen now.

b. alyawma Ratmamtu Salaykum nifmatii (alMaa?idah, verse 3)

today I completed-1sm-nom upon you my blessing By today I have completed my blessing upon you.

c. Rajiiu Piða ịmmarra al-busru al-Sahar al-qaadim. came-1sm when becomes ripe-3sm the dates-nom themonth next

I shall come when the dates ripen next month.

d. kullama daxal-a Salayha Zakaria al-mihraab-a wajada Sindaha rizqan.

Every time he entered upon her, Zakaria the chamber of prayer he found with her provision. (al-imraan, verse 37)

e. halla kallamt-a Rabaaka radan.

You should called-2sm father-acc-your tomorrow You should call your father tomorrow.

f. lan yadrus-a Sami radan. 
neg study-3sm-acc Sami tomorrow

Sami will not study tomorrow.

g. lam yadrus Sami Pams.

neg study-3sm-juss Sami yesterday

Sami did not study yesterday.

In these examples, the morphological forms faial and yafial do not represent the default tense. For example, in (23a) biftuka is in the past tense form but it refers to the present tense as evidenced by the use of the adverb Palaan. The verb ?atmamtu in (23b) even though it is in the past it represents the present tense as can be proven by the use of alyawma. ihmarra in (23c) is in the past tense form but actually it expresses the future because it is used with conditional Piða and furthermore the future tense adverb alfahar al-qaadim is used. daxala and wajada in (23d) represent the present tense expressing habitual actions. In (23 e) an instigation particle halla changes the tense of the verb kallamta to a future as evidenced by the use of the adverb radan. The negative particle lan makes the tense of yadrusa future since the future adverb radan is used. Finally, lam reverses the tense of the verb yadrus from present to past tense.

These examples clearly illustrate that it is not the morphological form that determines tense. This result is supported by the conclusions of Fassi Fehri (1993) and Juhfah (2006). I argue that the syntactic context determines the tense specification of the verb. As a result, the tense is developed and checked syntactically by means of verb movement as assumed in the minimalist program as can be illustrated in (24):

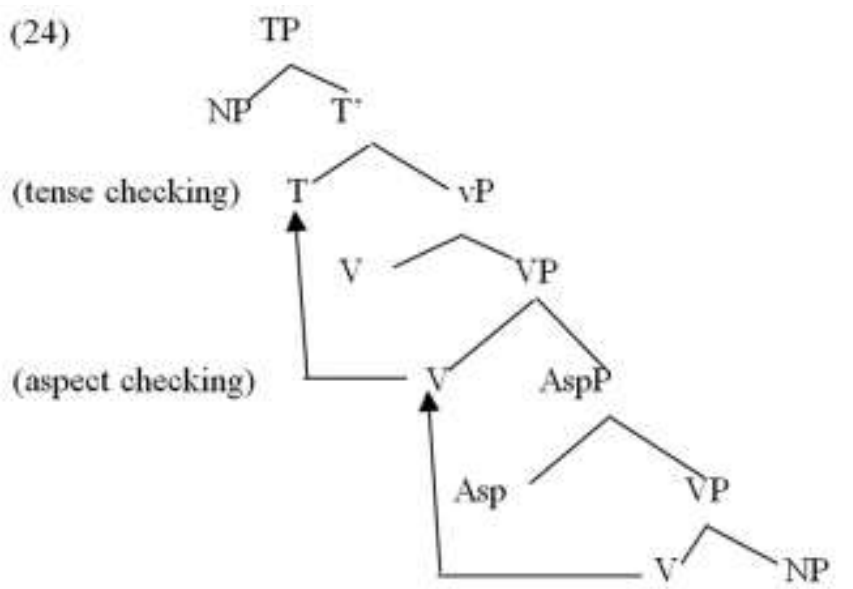

The verb moves first to check its aspect by agreeing with the aspect head and from there it moves to $\mathrm{T}$ to check the tense where the tense is represented in terms of features. So for example ?atmamtu in (23b) moves to $\mathrm{V}$ to check its aspect, which is telic or perfective and then moves to $\mathrm{T}$ to check the [+present] feature tense.

\section{CONCLUSION}

I reviewed the early Arab literature of tense and aspect and discussed the problems of the morphological analysis of tense. Then I reviewed some modern studies of Arabic tense and aspect like Fassi Fehri (1993), and Juhfah (2006). After that, I examined some of the problematic Arabic data in tense and aspect. It is illustrated that the traditional morphological view of Arabic verb cannot determine tense and aspect. Instead, I provided a syntactic analys is of tense and aspect based on MacDonald's (2008) analysis with some modifications needed to account for the Arabic data. More specifically, I have shown that MacDonald's analys is as well as Juhfah's analysis (2006) relied primarily on the internal object determining the telicity of the verb event. However, I have illustrated that beside the internal object other internal arguments of the VP like oblique arguments and internal object of intransitive achievements or unaccusatives also affect the telicity of the verb. Finally, I have shown that tense and aspect can be easily handled through the verb successive movement to $\mathrm{V}$ and $\mathrm{T}$ to check the aspect and tense features respectively.

\section{ACKNOWLEDGMENTS}

This research is funded by the Research Centre in the College of Arts at King Saud University for funding this research.

\section{END NOTES}

1 In his analysis, MacDonald uses the well-known VP-Shell that was originally developed by Larson (1988) to account for the double object construction. In such structure, the VP is split into two shells: the light head $v$ with a causative interpretation taking a VP as its complement. See Larson (1988) and Radford (2009: 295) for more details.

2 C-command is a syntactic relation organising the word order between nodes in a syntactic tree. It is defined as: A ccommands B if neither A nor B includes the other and every node dominating A also dominates B (Chomsky 1986a).

3 Even though the end feature is not projected to the Asp, it nonetheless contributes to the interpretation of the sentence by putting an end to the event. The verb yasqut in (18) without kaada has two features a beginning and end expressing that event begins and ends at the same time. Therefore, the event is telic. But syntactically only the beginning feature becomes visible by projecting to the higher node Asp. Of course, kaada in (18) modifies the beginning part of the event which cancels the result of the event.

4 The goal modifier in (21b) should be distinguished from MacDonald's modifier to his boss in (20) where the former modifies the place and answer a question, 'where does he push the car?' while the latter is not. Hence the modifier nahwa mahatati ilraazi works as a place destination by which the event reaches its goal and ends. This is not the case for to his boss.

\section{REFERENCES}

Alfarahiidi, K. A. (1985). Kitaab aljumal fii annahw. tahqiiq by F. Qabaawah. Beirut, Lebanon: Alrisaalah Publishing Company. 
Alhataari, A. A. (2006). taḥawlaat alafiaal fii alsiiyaaq alquraanii wa?athruruha albalaarii. In majalat aldiraasaati alijtimaaÀiyah. 22

Almaxzumii, M. (1986). fii annahw al Sarabiy: naqadun wa tawjiih. Beirut, Lebanon: Daar alraa?id alYarabiy.

Almalaax, M. (2009). Azzaman fii allurati al Sarabiyah: binyaatih attarkiibiyat wa addalaaliyah. Beirut, Lebanon: Arabic Scientific Publishers, Inc.

Almatlabii, M. Y. (1986). Azzaman wa allurah. Cairo, Egypt: Alhayati almasriyati aliaamti lilkitaab.

Alzajaajii, A. (1974). alidaah fii Silali annahw. taḥqiiq by M. alMubaark. Cairo: Daar alnafaa?is .

asSakkaaki, A. (2000). Miftaah alৎuluum. Tahiqiiq A. Hendawii. Beirut: Daar alkutub alilmiyyah.

Binnick, R. I. (1991). Time and the verb: a guide to tense and aspect. Oxford: Oxford University Press.

Chomsky, N. (2015). The Minimalist Program. 20 Anniversary Edition. Cambridge, Mass.: MIT Press.

Chomsky, N. (1986a). Barriers. Cambridge, Mass.: MIT Press.

Fassi Fehri, A. (1993). Issues in the structure of Arabic clauses and words. Dordrecht: Kluwer Academic Publishers.

Haegmen, L. (1994). Introduction to government and binding theory. Oxford: Blackwell.

Hasan, A. (no date). anNaḩaw alWaafii. Vol. 1 and Vol. 4, Cairo: Daar alMaSaarif.

Ibn Saashuur, M. (no date) tafsiir attahriir wa attanwiir. Tunis: Daar Sahnuun lilanshar wa attawziis.

Ibn Jenni, A. (1952). alkhasaa?is. tahqiiq M. Ali. Beruit: Daar alkitaab aliarabiy.

Ibn YaSiish, A. (no date) sharh almufassal. Cairo: Idaarat attibaaSati almuniiriyah.

Juhfah, A. (2006). Dalaalatu azzamani fii al Sarabiyah: diraasatu annasaqi azzamaniy lilas Saal. Morocco: Daar tubqaal lilnashr.

Larson, R. (1988). On the double object construction. In Linguistic Inquiry, 19(3), pp. 335-391.

MacDonald, J. (2008). The Syntactic Nature of Inner Aspect: A minimalist perspective. Philadelphia: John Benjamin's publishing Company Amsterdam.

Pustejovsky, J. (1991). The syntax of event structure. In cognition, 41, pp. 47-81.

Radford, A. (2009). An Introduction to English Sentence Structure. Cambridge: Cambridge University Press.

Sibawayhi, A. (1992). Kitaabu Sibawayhi. Vol. 3, tahqiiq A. Haaroun. Cairo: Maktabatu alxaanjii.

Sibawayhi, A. (1998). Kitaabu Sibawayhi. Vol. 1, tahqiiq A. Cairo: Haaroun. Maktabatu alxaanjii.

Tenny, C. (1987). Grammaticalizing aspect and affectedness. Ph.D. thesis. MIT.

Vendler, Z. (1967). Linguistics in philosophy. Ithaca: Cornell University Press.
Wright, W. (1974). A grammar of Arabic Language. Beirut: Librairie du Liban. 